\title{
PENGARUH BIAYA PROMOSI TERHADAP VOLUME PENJUALAN MOTOR PADA SENTRAL YAMAHA JEMBER TAHUN 2016-2018
}

\author{
Dewi Masruroh $^{1}$, Joko Widodo' ${ }^{1}$, Mukhamad Zulianto ${ }^{1}$ \\ ${ }^{1}$ Program Studi Pendidikan, Fakultas Keguruan dan Ilmu Pendidikan, Universitas Jember \\ e-mail: dewimasruroh612@gmail.com
}

\begin{abstract}
Abstrak
Berkembangnya teknologi menyebabkan meningkatnya kebutuhan manusia terhadap teknologi itu sendiri, salah satu contoh yaitu pada bidang transportasi. Kebutuhan akan kendaraan untuk setiap kegiatan masyarakat meningkat. Hal ini di tandai dengan banyaknya dealer sepeda motor yang berada di Indonesia dengan berbagai macam merk produk khususnya di Jember. PT. Roda Sakti Surya Megah (Sentral Yamaha Jember) adalah perusahaan yang bergerak di bidang dealer penjualan resmi sepeda motor merer Yamaha di Kota Jember. Adapun tujuan dari pelaksanaan penelitian ini adalah untuk mengetahui apakah ada pengaruh yang signifikan biaya promosi terhadap volume penjualan motor pada Sentral Yamaha Jember. Adapun penelitian yang telah dilakukan oleh peneliti ini merupakan penelitian kuantitatif dengan metode pengumpulan data yang digunakan terdiri dari metode wawancara dan dokumen. Jumlah sampel dalam penelitian ini yaitu 36 dengan teknik pengambilan sampel yang dilakukan purpose sampling Analisis data yang digunakan adalah analisis inferensial. Adapun hasil dari penelitian yang telah dilakukan oleh peneliti ini akan menunjukkan bahwa biaya promosi berpengaruh signifikan erhadap volume penjualan sepeda motor pada Sentral Yamaha Jember sebesar $82,6 \%$ sedangkan $17,4 \%$ dipengaruhi faktor lain yang tidak diteliti seperti selera konsumen, kualitas produk dan lain-lain.
\end{abstract}

Kata Kunci: Metode Biaya Promosi, Kuantitatif, Volume Penjualan

\section{PENDAHULUAN}

Kemajuan teknologi menyebabkan kebutuhan akan kendaraan untuk setiap kegiatan masyarakat meningkat. Hal ini di tandai banyaknya dealer sepeda motor yang muncul di Indonesia. Persaingan usaha terus dilakukan oleh para pelaku usaha yang memasarkan sepeda motor. Untuk dapat terus bertahan dengan usaha yang dijalani perusahaan dituntut untuk melakukan strategi promosi dengan baik. Untuk meningkatkan daya saing, perusahaan harus dapat menggunakan suatu cara atau strategi yang tepat agar perusahaan tersebut akan dapat mencapai tingkat penjualan yang diinginkan dan mendapatkan laba dari hasil penjualan. Suatu perusahaan dalam melakukan suatu kegiatan promosi harus melakukan pengeluaran untuk biaya promosi, dimana besarnya biaya promosi yang ditetapkan oleh perusahaan untuk memasarkan produk kepada konsumen akan sangat berpengaruh terhadap perkembangan gerak produsen dan pertumbuhan pasar konsumen (Tjiptono, 2008:218).

Pada sebuah perusahaan distributor, naik turunnya volume penjualan akan sangat berpengaruh terhadap pertumbuhan sebuah usaha yang telah di didirikan dan berjalan serta kelangsungan hidup produk yang dipasarkan oleh perusahaan yang telah berdiri tersebut. Jika perusahaan mengalami kenaikan hasil penjualan, maka produk akan dapat semakin berkembang dan akan mendapat tempat utama dalam pasar konsumen, demikian juga sebaliknya. Perusahaan sangat mementingkan hasil volume penjualan yang di dapat agar dapat mempertahankan usaha yang didirikannya.

PT. Roda Sakti Surya Megah (Sentral Yamaha Jember) adalah perusahaan yang bergerak di bidang dealer penjualan resmi sepeda motor merek Yamaha di Kota Jember. Perusahaan ini menjual bermacam-macam tipe sepeda motor merek Yamaha. PT. Roda Sakti Surya Megah dapat memenuhi keinginan konsumen, sehingga tujuan perusahaan dapat tercapai. 
PT. Roda Sakti Surya Megah melakukan strategi promosi dengan memanfaatkan beberapa media untuk mempromosikan produknya. Selain itu melakukan promosi penjualan dengan cara memberikan bonus jaket, helm, dan paket servis untuk setiap pembelian satu unit sepeda motor. Program publisitas juga dilakukan untuk penyajian promosi, penyebaran ide, barang dan jasa yang dilakukan oleh pihak yang melakukan sponsorship.

PT. Roda Sakti Surya Megah merupakan perusahaan yang selalu berusaha untuk memperkenalkan secara langsung kepada konsumennya agar mereka lebih mengenal produk yang dijual di dalam perusahaan yang diteliti ini dan tertarik untuk membeli produk sepeda motor Yamaha tersebut. Strategi promosi yang diterapkan PT. Roda Sakti Surya Megah ini membutuhkan biaya. Manajemen biaya promosi yang efektif dan efisien dalam memanfaatkan biaya promosi yang dikeluarkan perusahaan ini akan menghasilkan suatu pencapaian penjualan yang diinginkan perusahaan dan laba yang maksimal. Berdasarkan penjelasan diatas, penelitian ini bertujuan untuk mengetahui adakah pengaruh biaya promosi terhadap volume penjualan motor pada Sentral Yamaha Jember tahun 2016 sampai dengan tahun 2018.

\section{METODE}

Penelitian ini adalah penelitian kuantitatif yang dilaksanakan pada perusahaan yang bergerak pada bidang penjualan sepeda motor di Jember. Jumlah sampel yang digunakan dalam penelitianxini yaitu 36 sampel Metode pengumpulan data yang digunakan dalam penelitian ini adalah menggunakan metode dokumen dan wawancara dengan teknik pengambilan sampel dilakukan dengan suatu metode yang dimana pengambilan data sesuai tujuan peneliti disebut juga purpose sampling. Data yang digunakan untuk diuji yaitu data biaya promosi yang dikeluarkan perusahaan dan volume penjualan yang dihasilkan selama tahun 2016 sampai dengan tahun 2018. Analisis data yang digunakan adalah analisis regresi linier sederhana, analisis varian regresi, uji $\mathrm{F}$ dan analisis efektifitas garis regresi. Untuk memudahkan perhitungan analisis data maka peneliti menggunakan bantuan program SPSS 23.0 for windows.

\section{HASIL DAN PEMBAHASAN \\ Hasil Penelitian}

Berikut ini data biaya promosi dan volume penjualan pada Sentral Yamaha Jember tahun 2016 sampai dengan 2018.

Tabel 1. Biaya Promosi pada Tahun 2016-2018

\begin{tabular}{|c|c|c|c|}
\hline Bulan & $\begin{array}{l}\text { Biaya Promosi } \\
\text { Tahun } 2016\end{array}$ & $\begin{array}{c}\text { Biaya Promosi } \\
\text { Tahun } 2017\end{array}$ & $\begin{array}{c}\text { Biaya Promosi } \\
\text { Tahun } 2018\end{array}$ \\
\hline Januari & Rp. 99.780.000 & Rp. 94.100 .000 & Rp. 94.320 .000 \\
\hline Februari & Rp. 97.500 .000 & Rp. 93.100.000 & Rp. 92.980.000 \\
\hline Maret & Rp. 98.300 .000 & Rp. 94.700 .000 & Rp. 94.990 .000 \\
\hline April & Rp. 99.800 .000 & Rp. 94.900 .000 & Rp. 95.980.000 \\
\hline Mei & Rp. 98.100 .000 & Rp. 95.000.000 & Rp. 99.780 .000 \\
\hline Juni & Rp. 99.900 .000 & Rp. 94.780 .000 & Rp. 94.310.000 \\
\hline Juli & Rp. 96.900 .000 & Rp. 94.340 .000 & Rp. 94.650 .000 \\
\hline Agustus & Rp. 95.200.000 & Rp. 95.640.000 & Rp. 97.960.000 \\
\hline September & Rp. 97.600.000 & Rp. 94.910.000 & Rp. 94.880 .000 \\
\hline Oktober & Rp. 98.800 .000 & Rp. 95.980.000 & Rp. 98.670.000 \\
\hline November & Rp. 98.000 .000 & Rp. 98.950.000 & Rp. 98.450 .000 \\
\hline Desember & Rp. 99.800 .000 & Rp. 95.430 .000 & Rp. 99.600 .000 \\
\hline Jumlah & Rp. 1.179.680.000 & Rp.1.141.830.000 & Rp.1.156.570.000 \\
\hline
\end{tabular}

Sumber Data : Sentral Yamaha Jember (2019) 
Tabel diatas dapat dilihat jumlah biaya promosi yang dikeluarkan oleh Sentral Yamaha Jember selama waktu 3 tahun trakhir. Adapum jumlah biaya promosi yang dikeluarkan setiap tahun yaitu pada tahun 2016 sebesar Rp. 1.179.680.000, pada tahun 2017 biaya promosi yang dikeluarkan sebesar Rp. 1.141.830.000, pada tahun 2018 biaya promosi yang dikeluarkan sebesar Rp. 1.156.570.000. Penurunan biaya promosi terjadi pada tahun 2017 hal ini bila tidak diatasi maka akan berpengaruh terhadap volume penjualan pada masa yang akan datang. Ada beberapa faktor yang mengakibatkan penurunan biaya promosi pada Sentral Yamaha Jember yaitu : arus perputaran kas masuk yang kurang baik, banyak masyarakat yang mengambil cicilan sepeda motor jangka panjang dengan biaya cicilan yang kecil dengan tujuan tidak memberatkan mereka, Hasil penjualan yang semakin menurun pada tahun 2017, Disisi lain dengan adanya fenomena tersebut maka akan berdampak pada biaya promosi yang semakin menurun setiap tahunnya, jika masyarakat membeli sepeda motor dengan cara pembelian tunai maka perputaran kas juga akan cepat dan berdampak pada biaya promosi yang dikeluarkan.Berikut ini merupakan data hasil penujualan Sentral Yamaha Jember Tahun 2016-2018

Tabel 2. Hasil Penjualan Motor Pada Sentral Yamaha Jember Tahun 2016-2018

\begin{tabular}{lccc}
\hline \multicolumn{1}{c}{ Bulan } & $\begin{array}{c}\text { Hasil Penjualan } \\
\text { Tahun 2016 }\end{array}$ & $\begin{array}{c}\text { Hasil Penjualan } \\
\text { Tahun 2017 }\end{array}$ & Hasil Penjualan Tahun 2018 \\
\hline Januari & 929 & 564 & 566 \\
\hline Februari & 786 & 464 & 501 \\
\hline Maret & 909 & 647 & 592 \\
\hline April & 922 & 576 & 642 \\
\hline Mei & 980 & 655 & 801 \\
\hline Juni & 970 & 648 & 586 \\
\hline Juli & 712 & 552 & 626 \\
\hline Agustus & 671 & 622 & 678 \\
\hline September & 721 & 548 & 849 \\
\hline Oktober & 743 & 649 & 881 \\
\hline November & 736 & 749 & 8.363 \\
\hline Desember & 845 & 669 & \\
\hline Jumlah & 9.924 & 7.343 & \\
\hline Sumber Dat & Sent & & \\
\hline
\end{tabular}

Sumber Data : Sentral Yamaha Jember (2019)

Berdasarkan tabel diatas, maka dapat kita lihat hasil penjualan yang diperoleh setiap bulan pada Sentral Yamaha Jember tidak menentu dalam 3 tahun terakhir dari tahun 2016 sampai dengan tahun 2018. Dengan total setiap tahun dimulai dari tahun 2016 yaitu sebesar 9.924 unit sepeda motor terjual, pada tahun 2017 sebear 7.343 unit sepeda motor tejual, pada tahun 2018 sebesar 8.363 unit sepeda motor terjual. Tahun 2017 merupakan tahun yang mengalami penurunan volume penjualan hal ini terjadi disebabkan oleh beberapa faktor yaitu : penggunaan biaya promosi yang kurang optimal terhadap kegiatan promosi yang dilakukan disebabkan keadaan pangsa yang tidak menentu dengan kata lain yaitu perubahan selera masyarakat yang sangat cepat, Kondisi pasar yang tidak selalu baik ada pada bulan-bulan tertentu saja penjualan sepeda motor meningkat seperti waktu akan tiba perayaan hari raya, tahun baru dan tahun ajaran baru saja yang membuat masyarakat meningkatkan pembelian. Kondisi kemampuan penjual yang kurang optimal dalam bekerja. Faktor lainnya yaitu semakin tingginya jumlah kematian diakibatkan oleh kecelakaan sepeda motor, masih banyak masyarakat yang berfikir bahwa dengan sepeda motor maka akan mengancam nyawa, sedangkan pangsa pasar pada Sentral Yamaha Jember ini semua kalangan masyarakat. Hasil analisis regresi sederhana dengan menggunakan program SPSS 23.0 for windows.adalah sebagai berikut : 
Tabel 3. Hasil analisis regresi linier sederhana

Coefficients $^{\mathbf{a}}$

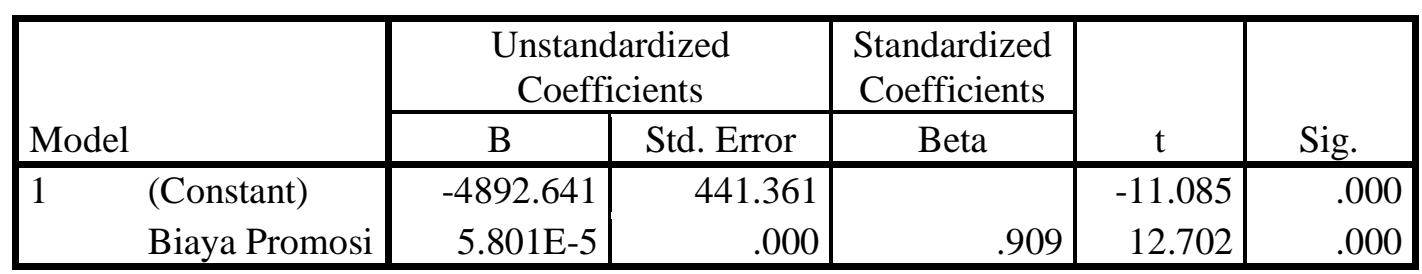

a. Dependent Variable: Volume Penjualan

Berdasarkan data diatas, maka persamaan regresi sederhana yang diperoleh dalam penelitian ini adalah sebagai berikut :

$$
Y=-4892,641+\mathbf{5 , 8 0 1}
$$

Adapun hasil perhitungan analisis varian garis regresi adalah sebagai berikut :

Tabel 4. Hasil interpretasi model summary

Model Summary ${ }^{b}$

\begin{tabular}{|l|r|r|r|r|}
\hline Model & R & R Square & Adjusted R Square & $\begin{array}{c}\text { Std. Error of the } \\
\text { Estimate }\end{array}$ \\
\hline 1 & $.909^{\mathrm{a}}$ & .826 & .821 & 58.89085 \\
\hline
\end{tabular}

a. Predictors: (Constant), Biaya Promosi

b. Dependent Variable: Volume Penjualan

Berdasarkan hasil data yang didapatkan seperti yang terlihat pada tabel diatas, maka diketahui besarnya nilai koefisien korelasi adalah 0,909. Koefisien korelasi sebesar 0,909 tersebut menunjukkan bahwa hubungan antara variabel biaya promosi $(\mathrm{X})$ terhadap volume penjualan (Y) di Sentral Yamaha Jember dikategorikan mempunyai tingkat hubungan yang sangat kuat.Nilai $R$ Square pada analisis data yang dilakukan adalah sebesar 0,826, sehingga hasil akhir setelah dimasukkan ke dalam rumus efektifitas garis regresi adalah sebagai berikut:

$$
\text { Rsquare } \times 100 \%=0,826 \times 100 \%=82,6 \%
$$

Hal ini menunjukkan bahwa besarnya presentase pengaruh biaya promosi terhadap volume penjualan motor pada Sentral Yamaha Jember adalah sebesar 82,6\%. Adaun perhitungan Uji F sebagai alat uji hipotesis pada penelitian ini adalah sebagai berikut :Adapun perhitungan dari uji $\mathrm{F}$ sebagai alat uji hipotesi pada penlitian ini adalah sebagai berikut :

Tabel 5. Hasil Uji F

ANOVA ${ }^{\mathrm{a}}$

\begin{tabular}{|ll|r|r|r|r|r|}
\hline Model & & Sum of Squares & df & Mean Square & F & Sig. \\
\hline 1 & Regression & 559511.387 & 1 & 559511.387 & 161.329 & $.000^{\mathrm{b}}$ \\
& Residual & 117916.502 & 34 & 3468.132 & & \\
& Total & 677427.889 & 35 & & & \\
\hline
\end{tabular}

a. Dependent Variable: Volume Penjualan

b. Predictors: (Constant), Biaya Promosi

Berdasarkan hasil dari tabel diatas dapat diketahui bahwa nilai $\mathrm{F}_{\text {hitung }}=161,329$. Sedangkan nilai dari $F_{\text {tabel }}=4,13$ dengan tingkat signifikansi $F=0,00$ maka nilai $F_{\text {hitung }}$ yang berjumlah 161,329 lebih besar daripada $\mathrm{F}_{\text {tabel }}$ yaitu 4,13 dan tingkat signifikansi juga lebih kecil dari 0,05 sehingga dapat disimpulkan bahwa ada pengaruh yang signifikan biaya promosi terhadap volume penjualan motor pada Sentral Yamaha Jember. 


\section{Pembahasan}

Berdasarkan hasil analisis data yang dilakukan dalam penelitian dapat diketahui bahwa biaya promosi yang telah ditetapkan dan dialokasikan terhadap beberapa kegiatan promosi oleh Sentral Yamaha Jember yang terdiri biaya periklanan, biaya promosi penjualan, biaya penjualan pribadi dan biaya hubungan masyarakat memiliki pengaruh yang signifikan terhadap volume penjualan yang didapat perusahaan. Hasil tersebut sesuai dengan hipotesis penelitian yaitu diduga ada pengaruh yang signifikan biaya promosi terhadap volume penjualan. Pengaruh sebesar $82,6 \%$ dikategorikan sangat tinggi karena $\mathrm{R}_{\text {Squaree }}$ sebesar 0,826 dan hampir mendekati 1. Biaya promosi yang dikeluarkan di dapat dari hasil penjualan perusahaan. Pengalokasian biaya promosi untuk beberapa kegiatan promosi yaitu biaya periklanan, biaya penjualan pribadi, biaya promosi penjualan dan biaya hubungan masyarakat.

Kegiatan periklanan yang dilakukan oleh Sentral Yamaha Jember yang membutuhkan biaya adalah promosi iklan melalui surat kabar yang terdapat di wilayah jember dan sekitarnya, seperti harian Radar Jember dengan tujuan agar produk dapat dikenal dan diketahui oleh masyarakat luas, melalui spanduk yaitu digunakan yang ditujukan untuk memperkenalkan produk yang dikeluarkan sehingga diharapkan menjadi tertarik untuk membeli produknya, juga memberitahu program-program kebijaksanaan kredit sehingga masyarakat yang melihat akan tertarik untuk membeli motor yang ditawakan, kemudian melalui radio perusahaan mempromosikan melalui program pada stasiun radio lokal, melalui pameran dibeberapa tempat perbelanjaan, ditujukan agar masyarakat mengetahui lebih dekat Sentral Yamaha Jember dan kebijaksanaanya terhadap produk yang dipamerkannya.

Biaya penjualan pribadi yang dialokasikan untuk kegiatan para tenaga pekerja pada Sentral Yamaha Jember melakukan komunikasi langsung kepada calon pelanggan membentuk pemahaman pelanggan terhadap produk sehingga tertarik untuk membeli, yang berhasil mendapatkan pembeli maka akan mendaptkan komisi dari hasil penjualan. Biaya promosi penjualan dialokasikan untuk kegiatan promosi berupa hadiah kepada konsumen berupa kupon undian, potongan harga, oli, pemberian jaket gratis, service dan lain-lain yang telah ditetapkan oleh Sentral Yamaha Jember, program undian merupakan salah satu kegiatan pengalokasian biaya promosi dengan maksud agar masyarakat tertarik untuk membeli produk perusahaan dengan cara menyediakan hadiah-hadiah dan kupon undian. Pengalokasian biaya promosi pada kegiatan masyarakat ini dilakukan untuk menjaga hubungan yang harmonis dengan masyarakat. Respon masyarakat dan konsumen terkait pelaksanaan kegiatan promosi yang dilakukan Sentral Yamaha Jember menjadi bukti pentingnya anggaran pembiayaan untuk hubungan masyarakat ini sejalan dengan pendapat yang dinyatakan oleh Lupiyoadi (2013:181) yang menyatakan "hubungan masyarakat merupakan kiat promosi penting dimana perusahaan tidak hanya harus berhubungan dengan pelanggan, pemasok, dan penyalur, tetapi juga harus berhubungan dengan kumpulan kepentingan publik yang lebih besar".

Hasil dari analisis data yang dilakukan menunjukkan bahwa biaya promosi berpengaruh secara sigifikan terhadap volume penjulan. Hal ini selaras dengan teori yang diungkapan oleh Buchari Alma (2005:157), "Bahwa pada umumnya apabila dana bertambah untuk kegiatan marketing maka jumlah penjualan meningkat" serta sejalan dengan pendapat Simamora (2002:762) "biaya Promosi merupakan sejumlah dana yang dikeluarkan perusahaan ke dalam promosi untuk meningkatkan penjualan”. Dengan demikian maka hipotesis dalam penelitian ini yang menduga bahwa ada pengaruh yang signifikan antara biaya promosi terhadap volume penjualan motor pada Sentral Yamaha Jember dapat diterima, sehingga tujuan penelitian ini telah tercapai. 


\section{PENUTUP}

Berdasarkan hasil penelitian dan pembahasan mengenai pengaruh biaya promosi terhadap volume penjualan motor pada Sentral Yamaha Jember dapat disimpulkan bahwa ada pengaruh yang signifikan biaya promosi terhadap volume penjualan motor pada Sentral Yamaha Jember yaitu sebesar $82,6 \%$, sedangkan sisanya yaitu $17,4 \%$ dipengaruhi variabel bebas lainnya yang tidak diteliti dalam penelitian ini seperti selera konsumen, kualitas produk dan lain-lain.

Berdasarkan kesimpulan diatas, maka penulis memberikan saran kepada beberapa pihak. Adapun saran yang dapat penuli berikan dalam penelitian ini yaitu bagi Sentral Yamaha Jember, diharapkan dapat memperhatikan kembali kebijaksanaan dalam menyusun anggaran biaya promosi supaya pihak pemasaran dapat melaksanakan kegiatan promosinya dengan optimal supaya volume penjualan produk sepeda motor Yamaha juga ikut meningkat.Sentral Yamaha Jember mencapai kinerja yang baik, perusahaan harus mengoptimalkan penggunaan dan pengelolaan biaya promosi yang dikeluarkan, karena pengaruh biaya promosi dapat mempengaruhi volume penjualan yang harus dihasilkan. Bagi Peneliti lain, diharapkan untuk ikut mempertimbangkan variabel bebas lain yang tidak diteliti pada penelitian ini seperti faktor harga, kualitas produk dan lain-lain.

\section{DAFTAR PUSTAKA}

Alma, B. 2004. Manajemen Pemasaran dan Pemasaran Jasa. Bandung: Alfabeta.

Lupiyoadi, R. 2013. Manajemen Pemasaran Jasa (Vol 3). Jakarta: Salemba Empat.

Nitisemito, A.S. 2000. Marketing. Jakarta: Ghalia Indonesia

Simamora, H. 2002. Akuntansi Manajemen. Jakarta: Salemba Empat.

Tjiptono, F. 2008. Strategi Pemasaran . Yogykarta: CV. Andi Offset

Yudi, R. 2015. Sejarah Yamaha Jatim. http://yamaha-jatim.co.id/home.php (Diakses pada 20

Februari 2019)

Catur, R. E. dan Ig. Bondan S. 2001. Pemasaran Barang dan Jasa . Cetakan pertama, Yoyakarta: penerbit : Kanisius 